\title{
Formulation and Evaluation of Nimodipine Tablet by Liquisolid Technique
}

\author{
Neha Durge ${ }^{1}$, Kirti Parida² \\ 1Student, ${ }^{2}$ Assistant Manager \\ 1Department of Pharmaceutics, Smt. Kishoritai Bhoyar College of Pharmacy, \\ 1 New Kamptee, Nagpur, Maharastra, India \\ ${ }^{2}$ Getz Pharma Research Private Limited, Ambarnath, Maharashtra, India
}

\begin{abstract}
How to cite this paper: Neha Durge | Kirti Parida "Formulation and Evaluation of Nimodipine Tablet by Liquisolid Technique" Published in International Journal of Trend in Scientific Research and Development (ijtsrd), ISSN: 24566470, Volume-3 | Issue-4, June 2019, pp.739-745, URL: https://www.ijtsrd.c om/papers/ijtsrd23 863.pdf

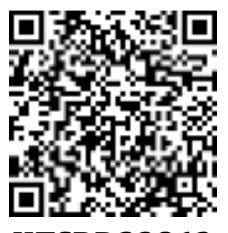
IITSRD23863
\end{abstract}

Copyright (C) 2019 by author(s) and International Journal of Trend in Scientific Research and Development Journal. This is an Open Access article distributed under the terms of the Creative Commons

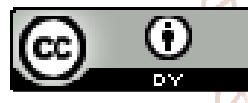
Attribution License (CC BY 4.0) (http://creativecommons.org/licenses/ by $/ 4.0$ )

\section{INTRODUCTION}

Oral route is most common and popular route of administration of drug because of its systemic effect, patient compliance, less expensive to manufacture, safe and effective etc. Tablet form is the most widely used dosage form because of self-administration and ease in manufacturing. Tablet provides high precision dosing. In most of the cases immediate on set of action is required as compare to conventional therapy. To achieve the rapid onset of action and eliminate the drawbacks of conventional therapy immediate release dosage form is now a days popular and used as a alternative oral dosage form. Immediate release tablets are very quickly absorbed after administration. Basic approach used in development is the use of superdisintegrants which provide rapid disintegration of tablet after administration. ${ }^{1}$

\section{Nimodipine}

belongs to the class of pharmacological agents known as a calcium channel blockers. Nimodipine is used as a antihypertensive and in subarachnoid hemorrhage and Arrhythmias. It increases blood flow to injured brain tissues. The bioavailability is $13 \%$ by oral route were $95 \%$ of protein binding. It get metabolise in liver and biological half life having 8-9 hours and drug is excreted from Faces and urine ${ }^{2}$.
Many techniques are being employed for the solubility enhancement of poorly soluble drugs to resolve the bioavailability issue due to inadequate dissolution rate. Various approaches make use of hydrophilic polymers as solubility enhancers acting through a variety of mechanisms such as amorphization, co-solvency, micelle formation or inclusion complexes $3,4,5$. These techniques impart many advantageous effects in the formulation development. But usually these approaches show lack of stability and decreasing success rate over a period of storage. One of the remarkable demerits of solid dispersions, glass solutions, eutectic mixtures and inclusion complexes is formation of sticky and hygroscopic mass resulting in the poor flow characteristics. Due to this set-back, industrial feasibility of the final dosage form becomes very difficult ${ }^{6,7,8}$.

The liquisolid technology emerged as a new drug delivery system distinguished by its characteristics and ability to deliver variety of drugs ${ }^{9,10}$. Liquisolid drug delivery system has gained attention of pharmaceutical researchers due to its contribution in the solubility enhancement as well as dissolution retarding approaches depending on the need and design of the formulation ${ }^{11,12,13}$. 
Three major components in the formulation of liquisolid compacts are liquid medication, carrier and coat material ${ }^{14}$.

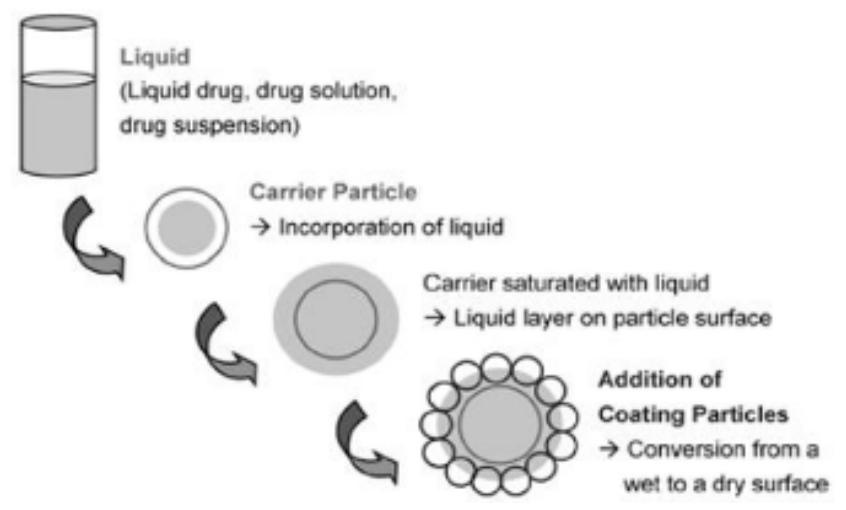

Fig.1: Concept of Liquisolid formulation

The aim of the present work is to increase the solubility and in-vitro dissolution of water insoluble drug Nimodipine by formulating it into liquisolid tablets. The liquisolid tablets are prepared by using Avicel PH 101, Avicel PH 102, Avicel PH 200 as carrier material, Aerosil as coating material, PEG 300 as liquid vehicle

\section{MATERIALS AND METH.ODS}

Nimodipine was purchased from Maxwell Life Science Pvt. Ltd. Mumbai, India. Avicel PH101, Avicel PH102, Avicel PH200 were purchased from FMC Biopolymer, Aerosil from Evonik, PEG 300 from Colorcon Asia ,Propylene Glycol from
Sigma Aldrich, Tween 80 from Merck, Crosspovidone from Nanhang, Sodium Laury Sulphate from Loba Chemical, Methanol from BP Chemicals, Magnesium stearate from Peter Greven. All other materials used were of Pharmaceutical grade.

\section{Solubility studies}

For the selection of best non-volatile solvents, solubility studies were performed. In this procedure, pure drug was dissolved in non-volatile solvents (propylene glycol and polyethylene glycol, Tween 80) . Excess amount of pure drug was added to the above solvents. Obtained saturation solutions were shaken on sonicator for 1 hours at $25^{\circ} \mathrm{C}$ under constant vibration. After 1 hours saturated solution were filtered and analyzed by UV spectrophotometer.

\section{Calculation of loading factor (Lf) and "q" value}

Loading factors were calculated for different carriers, using various solvents. By using Lf $=\mathrm{W} / \mathrm{Q}$ formula (W: Amount of liquid medication and Q: Amount of carrier material), the drug loading factors were obtained and used for calculating the amount of carrier and coating materials in each formulation. The results showed that if the viscosity of the solvent is higher, lower amounts of carrier and coating materials are needed to produce flowable powder. Based on $\mathrm{R}$ value used, the corresponding $\mathrm{q}$ (amount of coating material) can be calculated for all formulations using the equation $\mathrm{R}=\mathrm{Q} / \mathrm{q}$.

Table 1 represents the exact qualitative and quantitative composition for each formulation.

\begin{tabular}{|c|c|c|c|c|c|c|c|c|c|}
\hline Ingredients & \multicolumn{3}{|c|}{$\begin{array}{c}\text { Formulation code ( } \mathrm{mg}) \\
\text { (1:1 Ratio of drug }+ \\
\text { different vehicle) }\end{array}$} & \multicolumn{3}{|c|}{$\begin{array}{c}\text { Formulation code (mg) } \\
\text { (1:2 Ratio of drug } \\
+ \text { different vehicle ) }\end{array}$} & \multicolumn{3}{|c|}{$\begin{array}{c}\text { Formulation code (mg) } \\
\begin{array}{c}\text { (1: } 3,1: 4,1: 5 \text { Ratio } \\
\text { of drug + PEG } 300)\end{array}\end{array}$} \\
\hline \multirow{2}{*}{ Nimodipine } & $\mathrm{F} 1 \Rightarrow$ & $\mathrm{F} 2$ & DFe & $\mathrm{F} 4 \mathrm{pn}$ & F5 & F6 & F7 & F8 & F9 \\
\hline & 30 & 30 & 30 & 50 & 30 & 30 & 30 & 30 & 30 \\
\hline Tween 80 & 30 & & - & 60 & -8 & 2 & - & - & - \\
\hline Propylene glycol & - & 30 & -1 & & 00 & - & - & - & - \\
\hline Polyethylene glycol 300 & - & - & 30 & & & 60 & 90 & 120 & 150 \\
\hline MCC 101 & 55 & 55 & 55 & 110 & 110 & 80 & 140 & 110 & 110 \\
\hline MCC102 & 140 & 140 & 140 & 140 & 140 & 140 & - & - & 110 \\
\hline MCC200 & - & - & - & - & - & - & 220 & 220 & 110 \\
\hline PVP k30 & - & - & - & - & - & 30 & 10 & 20 & 20 \\
\hline Aerosil & 1.5 & 1.5 & 1.5 & 1.5 & 1.5 & 1.5 & 1.5 & 1.5 & 1.5 \\
\hline Crosspovidone & 2 & 2 & 2 & 2 & 2 & 2 & 2 & 2 & 2 \\
\hline Magnesium stearate & 1.5 & 1.5 & 1.5 & 1.5 & 1.5 & 1.5 & 1.5 & 1.5 & 1.5 \\
\hline Total weight of Tablet & \multicolumn{3}{|c|}{260} & \multicolumn{3}{|c|}{345} & 500 & 510 & 540 \\
\hline
\end{tabular}

\section{Manufacturing Procedure:-}

1. Dispense all the materials as per formula.

2. Nimodipine API was mixed with different vehicle such as tween 80,Propylene glycol, PEG300 with 1:1.1:2, 1:3.1:4,1:5 ratio.

3. Nimodipine was dispersed in Tween 80 or PG, PEG300, then added Microcrystalline cellulose $101,102,200$ it absorbed the liquid and get converted into powder form.

4. Then add PVP K30 binder and Crosspovidone and mix properly.

5. After that it get dried in hot air oven at $60^{\circ} \mathrm{C}$ for 1 hour.

6. Then the blend is pass through sieve no 20 .

7. To this blend add aerosil as a coating agent and mix with Magnesium stearate to enhance the flow.

8. After complete mixing compression of the tablet with punch pressure having size $7.5 \mathrm{~mm}$ or $10 \mathrm{~mm}$. 
International Journal of Trend in Scientific Research and Development (IJTSRD) @ www.ijtsrd.com eISSN: 2456-6470

\section{POST COMPRESSION ASSESMENT OF SUBLINGUAL TABLET}

The tablets of all the batches were evaluated for weight variation, drug content, hardness, thickness, disintegration time, wetting time, water absorption ratio, moisture content and in-vitro dissolution study.

Deight Variation: 10 tablets were selected randomly from each batch and weighed individually to check for weight variation. The following percentage deviation in weight variation is allowed as per USP.

Table No.4: Weight variation tolerances

\begin{tabular}{|c|c|}
\hline Average weight of a tablet & Percentage deviation \\
\hline $130 \mathrm{mg}$ or less & 10 \\
\hline$>130 \mathrm{mg}$ and $<324 \mathrm{mg}$ & 7.5 \\
\hline $324 \mathrm{mg}$ or more & 5 \\
\hline
\end{tabular}

$>$ Thickness and Diameter: The thickness and diameter of 4 tablets from each formulation were recorded during the process of compression using Vernier caliper.

> Hardness: Pharmatorn hardness tester was used for the determination of hardness of tablets. Tablet was placed in between the plungers and the force of the fracture was recorded.

Friability: 6.5 gm. of tablets were accurately weighed and placed in the friabilator (Electrolab, EF-2 Friabilator) and operated for 100 revolutions. The tablets were de-dusted and reweighed. Percentage friability was calculated using the following formula

$F=(1-W 0 / W) \times 100$

Where,

W0 is the weight of the tablets before the test and $\mathrm{W}$ is the weight of the tablet after the test. The tablets that loose less than $1 \%$ weight were considered to be satisfactory.

D Disintegration Time: Six tablets were taken and introduced in each tube of disintegration apparatus, and the tablet rack of the disintegration apparatus was positioned into a one liter beaker containing $900 \mathrm{ml}$ of distilled water and the time of disintegration was recorded. To discriminate between the formulations disintegration was done at room temperature and disk was not used for the study.

In-vitro Dispersion Time: Six tablets were taken for determination of dispersion time. Each tablet was placed in 6 ml $0.5 \%$ SDS in Water buffer solution, $\mathrm{pH} 7.0 \pm 0.5^{\circ} \mathrm{C}$. Time required for complete dispersion of a tablet was measured. predetermined time interval 10,20,30,45 min and replaced with same volume of fresh medium $0.5 \%$ SDS Water buffer. Absorbance of this solution was measured at $240 \mathrm{~nm}$.

2. Identification tests for Nimodipine

A. Melting point: The melting point of the Nimodipine was found to be $125^{\circ} \mathrm{C}$ which complies with melting point reported one.

B. UV Scanning: The $\lambda$ max of Nimodipine was found to be $240 \mathrm{~nm}$. This complies with specified $\lambda$ max.

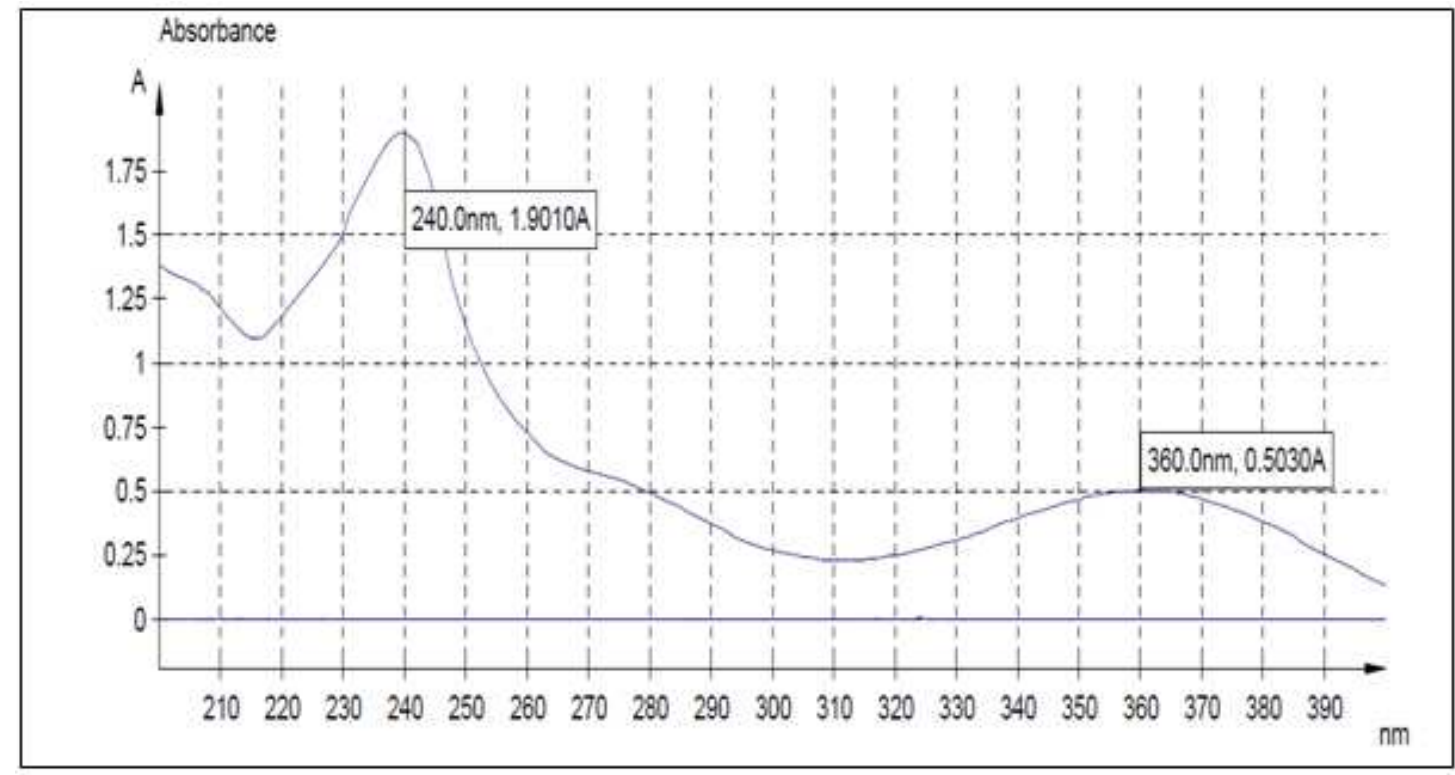

Fig.No.2. Scanning of Nimodipine 


\section{Infrared Absorption Spectrophotometry:}

Fig.No. 3 FTIR spectrum of Nimodipine

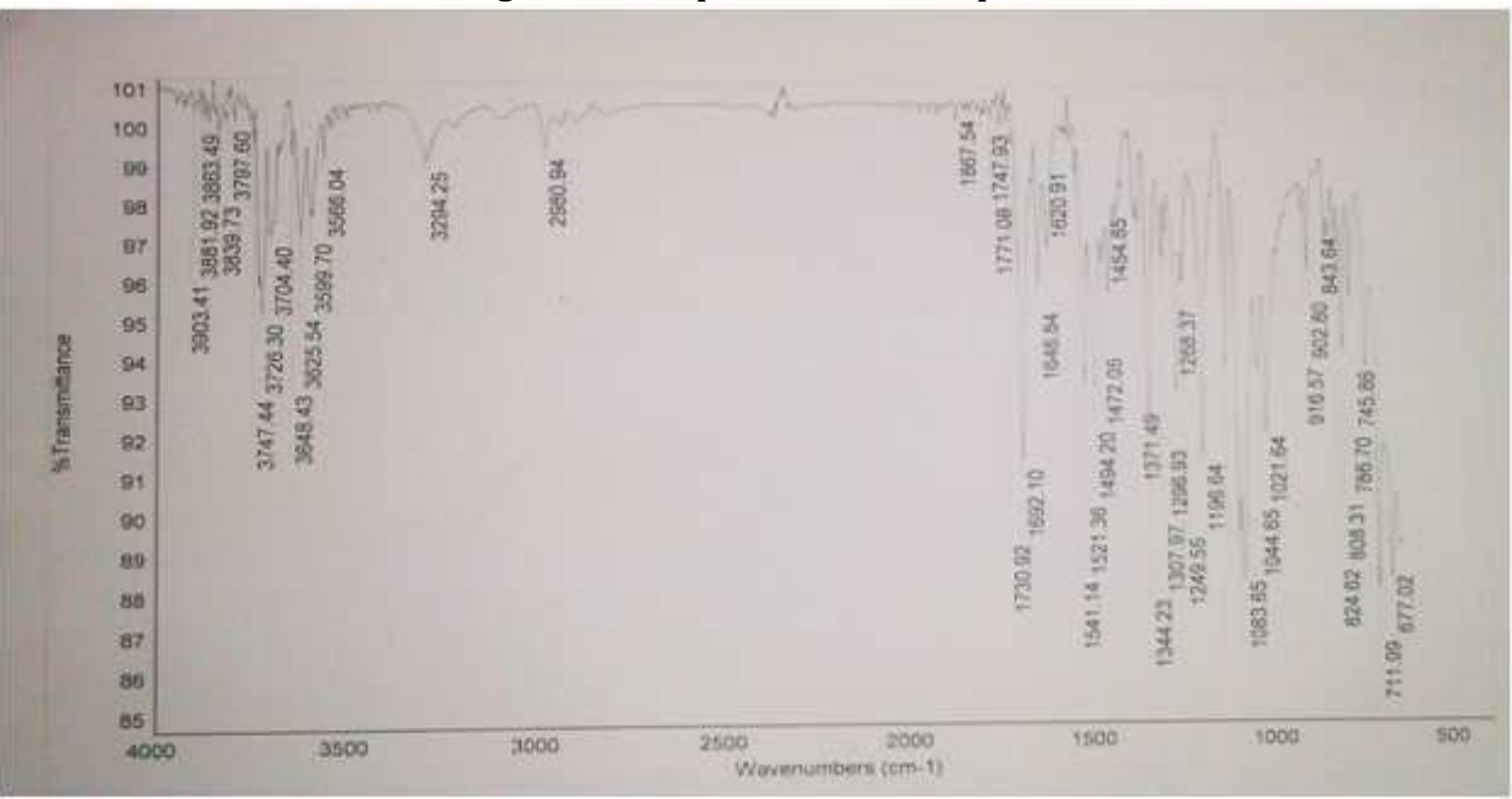

Table No.5 FTIR peaks of Nimodipine

\begin{tabular}{|c|c|c|}
\hline Sr. No. & Observed Frequency $\left(\mathrm{cm}^{-1}\right)$ & Assignment \\
\hline 1. & 1307.97 & $\mathrm{C}-\mathrm{N}$ \\
\hline 2. & 1730.92 & $\mathrm{C}=\mathrm{O}$ \\
\hline 3. & 745.86 & $\mathrm{C}-\mathrm{H}$ \\
\hline 4. & 1747.93 & $\mathrm{C}=\mathrm{C}$ \\
\hline 5. & 1541.14 & $\mathrm{~N}-\mathrm{H}$ \\
\hline 6. & 1646.84 & $\mathrm{C}=\mathrm{N}$ \\
\hline 7. & 677.02 & $\mathrm{C}-\mathrm{CI}$ \\
\hline 8. & 3903.41 & $\mathrm{O}-\mathrm{H}$ \\
\hline 9. & 824.62 & $\mathrm{C}-\mathrm{C}$ \\
\hline
\end{tabular}

A. Drug-Exipients Compatability study

Drug-Excipients Compatibility Study was carried out with different excipients with different ratio for initial, 15 days, 30 days.

Table No.6 Drug-Excipients compatibility study

\begin{tabular}{|c|c|c|c|c|c|c|}
\hline \multirow{3}{*}{$\begin{array}{l}\text { Sr. } \\
\text { no }\end{array}$} & \multirow{3}{*}{ Combination } & \multicolumn{5}{|c|}{ Physical Appearance } \\
\hline & & \multirow{2}{*}{ Initial } & \multicolumn{2}{|c|}{15 days } & \multicolumn{2}{|c|}{30 days } \\
\hline & & & Open & closed & Open & Closed \\
\hline 1 & Nimodipine & $\begin{array}{l}\text { Off yellow } \\
\text { powder }\end{array}$ & $\begin{array}{l}\text { Off yellow } \\
\text { powder }\end{array}$ & $\begin{array}{l}\text { Off yellow } \\
\text { powder }\end{array}$ & $\begin{array}{c}\text { Off yellow } \\
\text { powder }\end{array}$ & $\begin{array}{c}\text { Off yellow } \\
\text { powder }\end{array}$ \\
\hline 2 & Nimodipine +Mcc 101(1:1) & $\begin{array}{l}\text { Off yellow } \\
\text { powder }\end{array}$ & $\begin{array}{l}\text { Off yellow } \\
\text { powder }\end{array}$ & $\begin{array}{l}\text { Off yellow } \\
\text { powder }\end{array}$ & $\begin{array}{l}\text { Off yellow } \\
\text { powder }\end{array}$ & $\begin{array}{l}\text { Off yellow } \\
\text { powder }\end{array}$ \\
\hline 3 & Nimodipine+Mcc 102(1:1) & $\begin{array}{l}\text { Off yellow } \\
\text { powder }\end{array}$ & $\begin{array}{l}\text { Off yellow } \\
\text { powder }\end{array}$ & $\begin{array}{l}\text { Off yellow } \\
\text { powder }\end{array}$ & $\begin{array}{l}\text { Off yellow } \\
\text { powder }\end{array}$ & $\begin{array}{l}\text { Off yellow } \\
\text { powder }\end{array}$ \\
\hline 4 & Nimodipine+ Mcc 112(1:1) & $\begin{array}{l}\text { Off yellow } \\
\text { powder }\end{array}$ & $\begin{array}{l}\text { Off yellow } \\
\text { powder }\end{array}$ & $\begin{array}{l}\text { Off yellow } \\
\text { powder }\end{array}$ & $\begin{array}{l}\text { Off yellow } \\
\text { powder }\end{array}$ & $\begin{array}{l}\text { Off yellow } \\
\text { powder }\end{array}$ \\
\hline 5 & Nimodipine $+200(1: 1)$ & $\begin{array}{c}\text { Off yellow } \\
\text { powder }\end{array}$ & $\begin{array}{c}\text { Off yellow } \\
\text { powder }\end{array}$ & $\begin{array}{c}\text { Off yellow } \\
\text { powder }\end{array}$ & $\begin{array}{c}\text { Off yellow } \\
\text { powder }\end{array}$ & $\begin{array}{c}\text { Off yellow } \\
\text { powder }\end{array}$ \\
\hline 6 & Nimodipine + Tween $80(1: 0.5)$ & $\begin{array}{l}\text { Off yellow } \\
\text { powder }\end{array}$ & $\begin{array}{l}\text { Off yellow } \\
\text { powder }\end{array}$ & $\begin{array}{l}\text { Off yellow } \\
\text { powder }\end{array}$ & $\begin{array}{l}\text { Off yellow } \\
\text { powder }\end{array}$ & $\begin{array}{l}\text { Off yellow } \\
\text { powder }\end{array}$ \\
\hline 7 & $\begin{array}{l}\text { Nimodipine + propylene } \\
\text { glycol( } 1: 0.5)\end{array}$ & $\begin{array}{l}\text { Off yellow } \\
\text { powder }\end{array}$ & $\begin{array}{l}\text { Off yellow } \\
\text { powder }\end{array}$ & $\begin{array}{l}\text { Off yellow } \\
\text { powder }\end{array}$ & $\begin{array}{l}\text { Off yellow } \\
\text { powder }\end{array}$ & $\begin{array}{l}\text { Off yellow } \\
\text { powder }\end{array}$ \\
\hline 8 & $\begin{array}{l}\text { Nimodipine + Polyethylene } \\
\text { glycol }(1: 0.5)\end{array}$ & $\begin{array}{l}\text { Off yellow } \\
\text { powder }\end{array}$ & $\begin{array}{l}\text { Off yellow } \\
\text { powder }\end{array}$ & $\begin{array}{l}\text { Off yellow } \\
\text { powder }\end{array}$ & $\begin{array}{l}\text { Off yellow } \\
\text { powder }\end{array}$ & $\begin{array}{l}\text { Off yellow } \\
\text { powder }\end{array}$ \\
\hline 9 & $\begin{array}{c}\text { Nimodipine + PVP K } \\
30(1: 0.25)\end{array}$ & $\begin{array}{l}\text { Off yellow } \\
\text { powder }\end{array}$ & $\begin{array}{l}\text { Off yellow } \\
\text { powder }\end{array}$ & $\begin{array}{l}\text { Off yellow } \\
\text { powder }\end{array}$ & $\begin{array}{l}\text { Off yellow } \\
\text { powder }\end{array}$ & $\begin{array}{l}\text { Off yellow } \\
\text { powder }\end{array}$ \\
\hline 10 & $\begin{array}{c}\text { Nimodipine }+ \\
\text { Crospovidone }(1: 0.5)\end{array}$ & $\begin{array}{l}\text { Off yellow } \\
\text { powder }\end{array}$ & $\begin{array}{l}\text { Off yellow } \\
\text { powder }\end{array}$ & $\begin{array}{l}\text { Off yellow } \\
\text { powder }\end{array}$ & $\begin{array}{l}\text { Off yellow } \\
\text { powder }\end{array}$ & $\begin{array}{l}\text { Off yellow } \\
\text { powder }\end{array}$ \\
\hline 11 & Nimodipine + Aerosil(1:0.25) & $\begin{array}{c}\text { Off yellow } \\
\text { powder }\end{array}$ & $\begin{array}{l}\text { Off yellow } \\
\text { powder }\end{array}$ & $\begin{array}{l}\text { Off yellow } \\
\text { powder }\end{array}$ & $\begin{array}{l}\text { Off yellow } \\
\text { powder }\end{array}$ & $\begin{array}{l}\text { Off yellow } \\
\text { powder }\end{array}$ \\
\hline
\end{tabular}


International Journal of Trend in Scientific Research and Development (IJTSRD) @ www.ijtsrd.com eISSN: 2456-6470

3. PRECOMPRESSION EVALUATION OF LUBRICATED BLEND

Table No.7 Flowability parameter of Nimodipine Liquisolid compact.

\begin{tabular}{|c|c|c|c|c|c|}
\hline Sr. No. & Batch Code & Bulk Volume & Tap Volume & Bulk density & Tap Density \\
\hline 1. & F1 & 2.1 & 1.9 & 0.9523 & 1.0526 \\
\hline 2. & F2 & 4.8 & 4.3 & 0.4166 & 0.4651 \\
\hline 3. & F3 & 4.7 & 4.1 & 0.4255 & 0.4878 \\
\hline 4. & F4 & 4.9 & 4.2 & 0.4081 & 0.4761 \\
\hline 5. & F5 & 5.1 & 4.4 & 0.3921 & 0.4545 \\
\hline 6. & F6 & 5.4 & 4.3 & 0.3703 & 0.4651 \\
\hline 7. & F7 & 6.1 & 5.0 & 0.3278 & 0.4000 \\
\hline 8. & F8 & 6.2 & 5.2 & 0.3225 & 0.3846 \\
\hline 9. & F9 & 6.4 & 5.5 & 0.3125 & 0.3636 \\
\hline
\end{tabular}

Table No: 8. Flowability parameter of Nimodipine Liquisolid compact \begin{tabular}{|l|l|l|l|}
\hline Formulation code & Angle of Repose $(\boldsymbol{\theta})$ & Carr's Index & Hausner's Ratio \\
\hline
\end{tabular}

\begin{tabular}{|c|c|c|c|}
\hline F1 & 29.03 & 12.18 & 1.13 \\
\hline F2 & 29.05 & 10.42 & 1.11 \\
\hline F3 & 26.86 & 12.77 & 1.14 \\
\hline F4 & 28.62 & 14.28 & 1.16 \\
\hline F5 & 29.08 & 13.72 & 1.15 \\
\hline F6 & 27.15 & 20.38 & 1.25 \\
\hline F7 & 28.17 & 18.05 & 1.22 \\
\hline F8 & 28.96 & 16.14 & 1.19 \\
\hline F9 & 29.63 & 14.05 & 1.16 \\
\hline
\end{tabular}

\section{Evaluation of Liquisolid tablets:}

Table No:-9. Evaluation of Liquisolid tablets:-

\begin{tabular}{|c|c|c|c|c|}
\hline Formulation Code & $\begin{array}{c}\text { Thickness } \\
(\mathbf{m m})\end{array}$ & $\begin{array}{c}\text { Diameter } \\
(\mathbf{m m})\end{array}$ & Hardness (kg/cm $\left.{ }^{2}\right)$ & Disintegration time (min:sec) \\
\hline F1 & $4.29 \pm 0.02$ & $7.09 \pm 0.01$ & in Sc1.06 \pm 0.25 & $12 \mathrm{~min} 51 \mathrm{sec}$ \\
\hline F2 & $4.28 \pm 0.01$ & $7.13 \pm 0.02$ & rch $2.05 \pm 0.19$ & $14 \mathrm{~min} 34 \mathrm{sec}$ \\
\hline F3 & $4.29 \pm 0.07$ & $7.10 \pm 0.01$ & $1.09 \pm 0.30$ & $11 \mathrm{~min} 46 \mathrm{sec}$ \\
\hline F4 & $4.37 \pm 0.03$ & $10.24 \pm 0.10$ & $1.28 \pm 0.11$ & $12 \mathrm{~min} 32 \mathrm{sec}$ \\
\hline F5 & $4.38 \pm 0.05$ & $10.20 \pm 0.04$ & $456-2.62 \pm 0.28$ & $15 \mathrm{~min} 10 \mathrm{sec}$ \\
\hline F6 & $4.39 \pm 0.01$ & $10.05 \pm 0.06$ & $2.34 \pm 0.20$ & $19 \mathrm{~min} 54 \mathrm{sec}$ \\
\hline F7 & $6.38 \pm 0.02$ & $10.19 \pm 0.03$ & $2.44 \pm 0.15$ & $18 \mathrm{~min} 59 \mathrm{sec}$ \\
\hline F8 & $6.78 \pm 0.07$ & $10.21 \pm 0.09$ & $2.23 \pm 0.55$ & $14 \mathrm{~min} 10 \mathrm{sec}$ \\
\hline F9 & $8.15 \pm 0.15$ & $10.22 \pm 0.01$ & $3.27 \pm 0.12$ & $23 \mathrm{~min} 45 \mathrm{sec}$ \\
\hline
\end{tabular}

Mean \pm SD $n=3$

Table No:10. Evaluation of Liquisolid tablets

\begin{tabular}{|c|c|c|c|}
\hline Formulation code & Weight Variation (mg) & Friability (\%) & \% Drug content \\
\hline F1 & 262.6 & 0.25 & 96.78 \\
\hline F2 & 260.0 & 0.83 & 95.26 \\
\hline F3 & 262.2 & 0.22 & 96.20 \\
\hline F4 & 342.1 & 0.66 & 93.58 \\
\hline F5 & 344.1 & 0.49 & 97.51 \\
\hline F6 & 345.1 & 0.86 & 92.26 \\
\hline F7 & 505.2 & 0.42 & 101.22 \\
\hline F8 & 512.7 & 0.18 & 99.24 \\
\hline F9 & 542.3 & 0.36 & 95.18 \\
\hline Conventional & 547.3 & 0.16 & 94.96 \\
\hline
\end{tabular}

5. In- vitro Drug Release from Nimodipine Liquisolid Compact.

In-Vitro dissolution studies were carried out using USP apparatus type I at $50 \mathrm{rpm}$. Dissolution medium consist of $0.5 \%$ SLS in water maintained at $37^{\circ} \mathrm{C}$. Drug release at different time intervals was measured by UV-Visible Spectrophotometer at $240 \mathrm{~nm}$. In- vitro drug release drug release profile of all batches was compared with conventional formulation for drug release. 
International Journal of Trend in Scientific Research and Development (IJTSRD) @ www.ijtsrd.com eISSN: 2456-6470

Table No: 11. In- vitro release profile of immediate release Liquisolid tablet

\begin{tabular}{|c|c|c|c|c|c|c|c|c|c|c|}
\hline Time in min & \multicolumn{10}{|c|}{ Cumulative \% drug release } \\
\hline & F1 & F2 & F3 & F4 & F5 & F6 & F7 & F8 & F9 & Conventional Tablet \\
\hline 0 & 0 & 0 & 0 & 0 & 0 & 0 & 0 & 0 & 0 & 0 \\
\hline 5 & 32.34 & 31.98 & 36.67 & 34.67 & 35.89 & 32.34 & 41.61 & 62.51 & 56.94 & 62.46 \\
\hline 10 & 43.45 & 36.18 & 41.45 & 46.65 & 40.01 & 43.45 & 57.45 & 66.37 & 68.57 & 65.96 \\
\hline 15 & 48.89 & 43.39 & 47.47 & 50.91 & 46.13 & 48.89 & 63.45 & 70.86 & 72.31 & 70.98 \\
\hline 20 & 53.76 & 51.27 & 55.68 & 54.87 & 55.58 & 53.76 & 67.91 & 76.82 & 81.89 & 76.02 \\
\hline 25 & 55.85 & 57.89 & 60.76 & 58.76 & 61.19 & 55.85 & 70.15 & 88.31 & 85.64 & 89.41 \\
\hline 30 & 61.14 & 63.86 & 62.21 & 59.98 & 64.91 & 61.14 & 74.19 & 93.86 & 88.49 & 90.56 \\
\hline
\end{tabular}

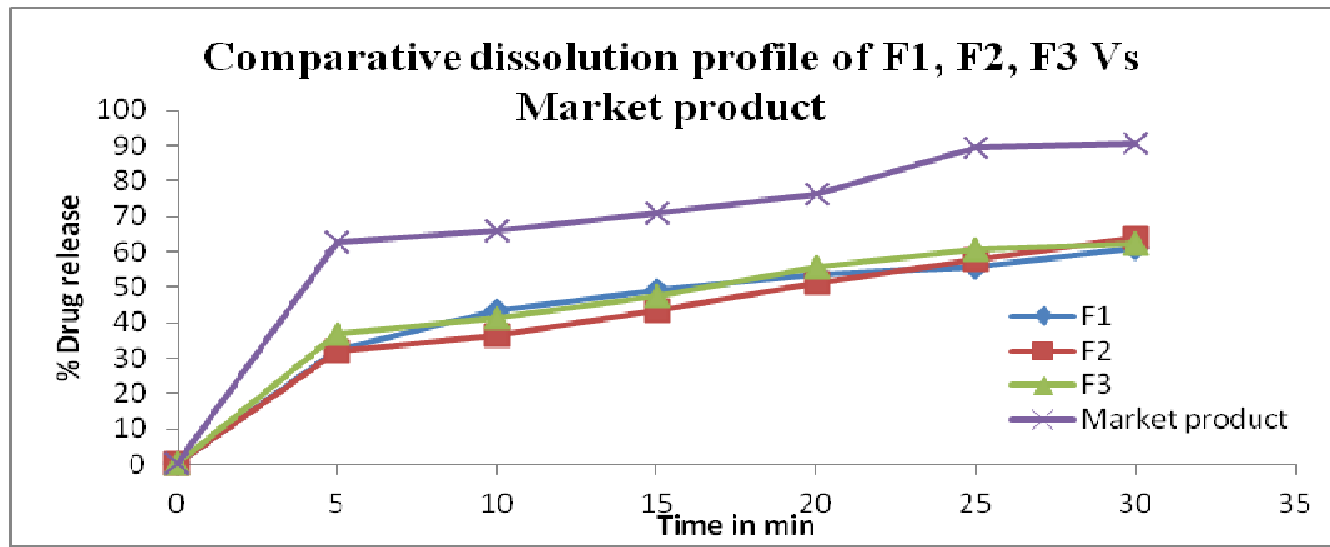

Figure No.4. In-Vitro release profile of tablet of batches F4, F5, F6 and Market product

It was observed that F4,F5,F6 prepared by liquisolid techniques using binder PVP K30 to gives 61.14\%,63.86\%,62.21\% drug release in $30 \mathrm{~min}$ and marketed preparation show $90.56 \%$ drug releae.F2 give better immediate action.

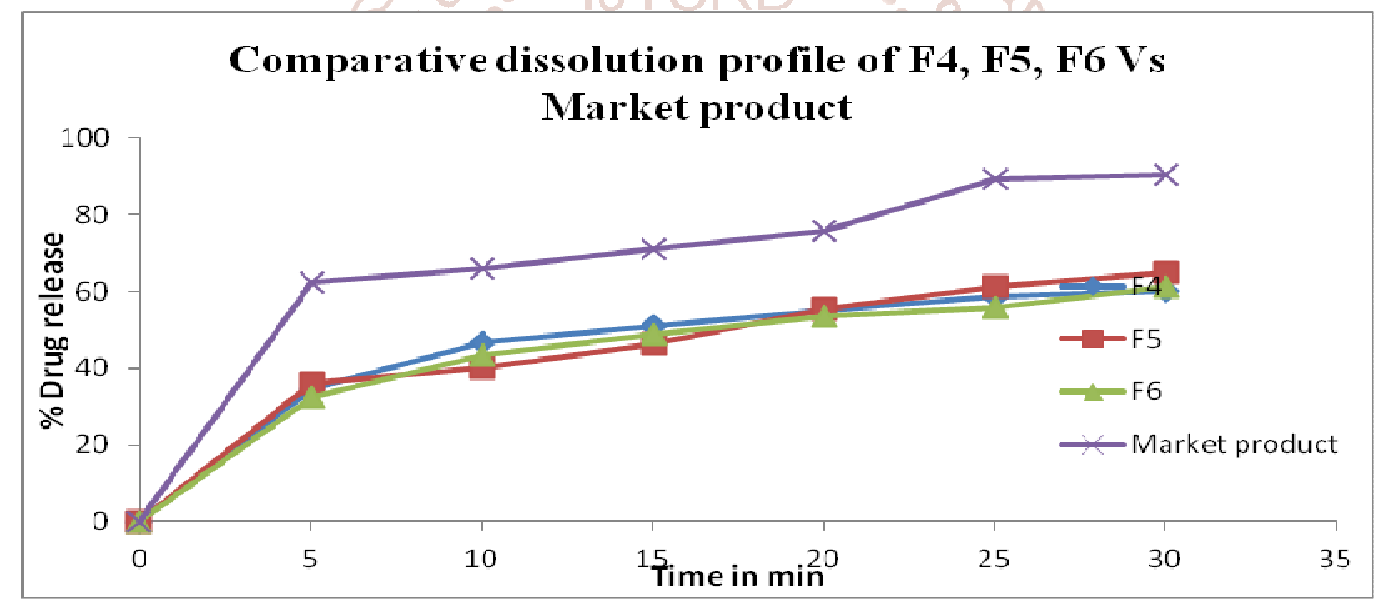

Figure No.5. In-Vitro release profile of tablet of batches F4, F5, F6 and Market product

It was observed that F4,F5,F6 prepared by liquisolid techniques using binder PVP K30 and disintegrants Crosspovidone to gives 59.98\%,64.91\%,61.14 drug release in $30 \mathrm{~min}$ and marketed preparation show $90.56 \%$ drug releae.F5 give better immediate action.

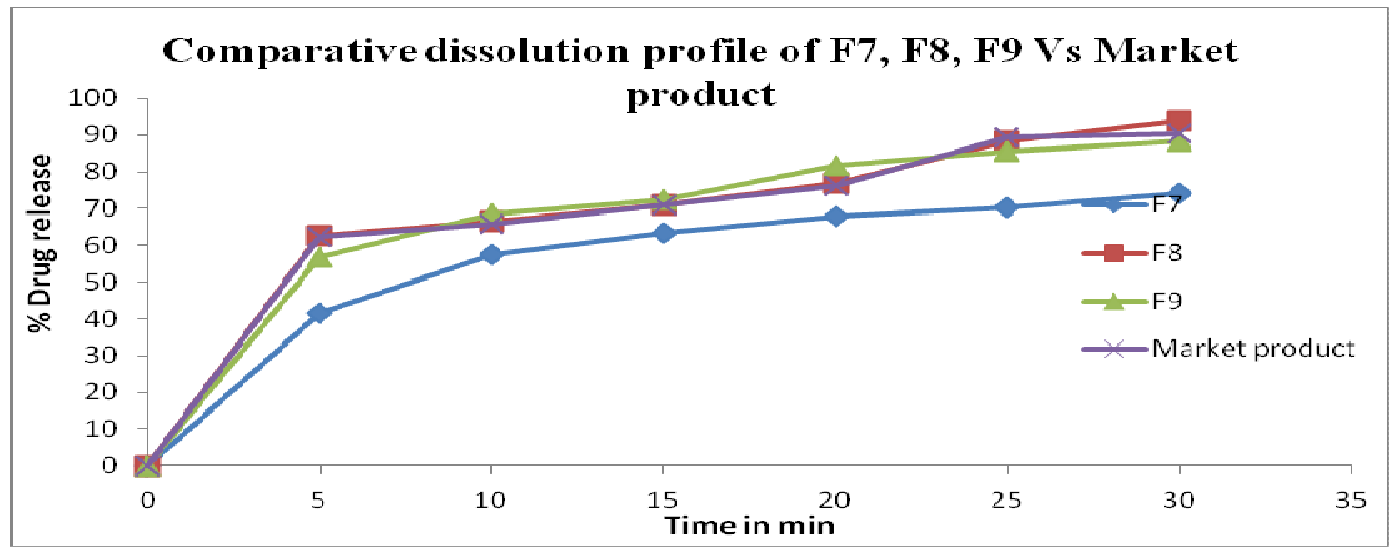

Figure No.6. In-Vitro release profile of tablet of batches F7, F8, F9 and Market product 
It was observed that F7,F8,F9 prepared by liquisolid techniques using binder PVP K30 and disintegrants Crosspovidone to gives $74.19 \%, 93.86 \%, 88.49 \%$ drug release in $30 \mathrm{~min}$ and marketed preparation show $90.56 \%$ drug releae.F8 give better immediate action.

It was found that immediate release liquisolid tablet prepared by using binder and disintegrate show immediate action and greater bioavailability. Formulation no.F8 was found to be optimized batch.

\section{SUMMARY AND CONCLUSION}

The present work showed that the liquisolid technique can be used for the production of immediate release matrices of water insoluble drug. PEG 300 was used as the liquid vehicle.

The prepared tablets were evaluated for tablet hardness, friability, thickness, weight variation, in-vitro disintegration time and dissolution. The hardness of all tablets was found to be $1.06 \pm 0.25-3.27 \pm 0.12 \mathrm{Kg} / \mathrm{cm}^{2}$. The hardness of all tablets were kept within the above mentioned range to compare the disintegration time of tablets prepared using different vehicle and their varying concentrations. The friability values were found in the range of $0.5-1 \%$. indicating that the tablets were mechanically stable and could handle rigors of transportation and handling. Thickness of all formulations was between $4.28 \pm 0.01$ to $8.15 \pm 0.15 \mathrm{~mm} /$ inch showing fairly uniform tablets. Out of the total formulations, the tablets made by using the Drug: vehicle with ratio 1:4 complex with Crospovidone showed faster disintegration and faster drug release.

From the study, it can be concluded that liquisolid technique showed better disintegration time and drug release. It can also be said that use of $7 \%$ crosspovidone as a disintegrating agent gave tablet with faster disintegration time.

In the present work, release studies showed that batch F8 is an optimized batch which gaves $62.51 \%, 66.37 \%, 70.86 \%$, $76.82 \%, 88.31 \%, 93.86 \%$ drug release in $0,5,10,15,20,25$, 30 minutes respectively. On the other hand conventional prepraion showed the $62.46 \%, 65.96 \%, 70.98 \%, 76.08 \%$, $89.41 \%, 90.56 \%$ drug release in 30 minutes respectively. Dissolution study was performed using USP Dissolution apparatus I (basket type), using $900 \mathrm{ml}$ dissolution medium $0.5 \%$ SLS in water with a rotation speed of $50 \mathrm{rpm}$.

The release of drug from these formulations provide evidence that PEG 300 play an vital role in immediate release of drug from liquisolid compact.

Thus, it can be concluded that formulation of Nimodipine tablet by Liquisolid Technique with appropriate ratio showed better disintegration time and percent drug release than other formulation. As all parameters were found satisfactory for small scale batch, it need to check commercial feasibility at larger scale. Hence it can be very well recommended for launching the proposed formulation in market with some desirable changes if required.

\section{REFERENCE}

[1] Jaimini M., Rawat S., Research Journal of Pharmaceutical, Biological and Chemical Sciences : A
Reviewon immediate drug delivery system, volume 4, issue 2, 2013, page no.1722-1725

[2] https://en.wikipedia.org/wiki/Nimodipine

[3] Jarowski CI., Rohera BD., Spireas S., Pharmaceutical Resesarch Powdered solution technology: Principles and Mechanism, Volume 9, 1990, page no. 1351-1358

[4] Baby D N., Saroj S., Sabitha M., International Journal of Pharmacy and Pharmaceutical Sciences Mechanism of solubility of liquisolid formulation in non volatile solvent: A Review. volume 4,2012, page no. 710-713

[5] Vemula S K., Katkum R ., Journal of Drug Research and Development: Liquisolid Compact Technique for improvement of the dissolution rate of flurbiprofen: formulation and Evaluation, SciForschen., Volume 1.1, 2015, page no. 1-4

[6] Rao S A., Naga A T., International Journal of Research in Pharmaceutical and Biomedical Sciences: Liquisolid Technology: An Overview, Volume 2 , Issue ,2 2011, page no. 401-408

[7] Patel H., Patel A, Patel V., International journal of pharmaceutical research and bioscience, liquisolid technique: a novel technique for enhancing dissolution rate of poorly soluble drug. volume 3 , issue 2,2014 , page no. 437-445

[8] Spireas S., Sadu S., Grover R., Journal of Pharmaceutical Science, In vitro release evaluation of hydrocortisone liquisolid tables, Volume 87, 1998,page no.867- 876

[9] Spireas S., Saud S., International Journal of Pharmaceutical Science, Enhancement of Prednisolone dissolution properties using Liquisolid compact, Volume 166, 1998, page no.177-88

[10] Anna B., Umashankar M S., Kavitha B., International journal of applied Pharmaceutics, Liquisolid Technology- A Latest Review. Academic Science, Volume 6, Issue1, 2014, page no.11-1513. Karamkar A B., Gonjari I D., Hosmani A H.,et al., International Journal of Health Research: Liquisolid tablets: A novel approach of drug delivery,Volume2, Issue 1, 2009, page no.45-50.

[11] Kulkarni A S., Aloorkar N G., Mane M S et al., International Journal of Pharmaceutical science and Nanotechnology, Liquisolid Systems: A Review, Volume 3 , Issue 1, 2010, page no. 135-142

[12] Syed I A., Pavani E., International Journal of Pharmaceutical Sciences and Drug Research The Liquisolid Technique: Based Drug Delivery System. Volume 4, Issue 2, 2012, page no. 88-93

[13] 13 Gavali S M., Pacharane S S., Sankpal S S et al., International journal of research in pharmacy and chemistry: Liquisolid compact: A new technique for enhancement of drug dissolution, Volume 1, Issue 3, 2011, page no. 705-710

[14] Beedha S., Meesa R., World journal of pharmacy and pharmaceutical sciences: Liquisolid Technology for enhancing the dissolution profile of Irbesartan by using different non volatile solvents and carrier materials, Volume 3, Issue 10, 2014, page no. 839-843 